\title{
Plant use from the grinding stones' viewpoint: Phytolith analyses from Aeneolithic Monjukli Depe, Turkmenistan
}

\author{
Birgül Ögüt
}

Institut für Vorderasiatische Archäologie, Freie Universität Berlin, Fabeckstr. 23-25, 14195 Berlin, Germany.

Email: ogut@zedat.fu-berlin.de

\begin{abstract}
:
Recent archaeological examinations include an increasing amount of natural science analyses. They are often carried out by external specialists and their results are often accepted by archaeologists without question. This may lead to incomplete integration of the results into an archaeological context. One of those methods, increasingly employed in the field of archaeology, is phytolith analysis. Phytoliths, microscopic silica bodies from genera-specific plant cells, allow searching for traces of plant material in archaeological contexts where methods based on macroscopic analysis have reached their limits. This paper combines natural science approaches with archaeological data by examining the social life of artefacts via phytolith analyses that can provide data to precisely determine the interpretation and variety of grinding stones, which are often misinterpreted. In this pilot study, the analyses confirmed the macroscopic observations for grinding plant material in some cases, but also opened new areas of study such as mineral-related activities, possible use of wooden implements and the connection between the different archaeological and botanical information. The analysed objects are grinding stones from Monjukli Depe, a small village in modern southern Turkmenistan that was occupied in the Neolithic and Aeneolithic periods. The site was excavated in the 1960s by Soviet archaeologists and restudied since 2010 by a team from the Free University Berlin.
\end{abstract}

Keywords: Monjukli Depe; Turkmenistan; Aeneolithic; phytolith analyses; grinding stones; ground stone tools

\section{Introduction}

The general framework for the study of grinding stones from Monjukli Depe, Turkmenistan (Figure 1) considers the socio-cultural context of artefacts by focusing on their biographies (e.g., Kopytoff 1986; Shanks 1998), integrated into the overall focus of the main excavation project. A detailed analysis of the sequence of use aims to reconstruct the interactions of people with artefacts as precisely as possible.

The site of Monjukli Depe in southern Turkmenistan is a small mound located north of the Kopet Dag mountain foothills. Excavated levels were dated to the Late Neolithic through the early Aeneolithic period. The first excavation by A. Maruschenko was a deep sounding, while the second by O. Berdiev exposed the site's uppermost Aeneolithic level (Berdiev

Published by the School of History, Classics and Archaeology, University of Edinburgh ISSN: 2055-0472. URL: http://journals.ed.ac.uk/lithicstudies/

This work is licensed under a Creative Commons Attribution 2.5 UK: Scotland License. 
1972). In 2010, a team from the Free University Berlin, under the leadership of S. Pollock and R. Bernbeck, began renewed excavations at the site. One of the goals of this ongoing investigation is the establishment of microhistories of technological change in the plains adjacent to the eastern Kopet Dag mountain foothills during the late Neolithic and earliest Aeneolithic periods (Pollock et al. 2011: 172). At present, the radiocarbon dates of the levels point to a Neolithic settlement between $c a$. cal. 6,100-5,650 BCE followed by a hiatus of $c a$. 850 years. The five grinding stones, which are the focus of this paper, are all from the Aeneolithic layers following the hiatus, which have ${ }^{14} \mathrm{C}$ dates of $c a .4,800-4,350$ cal. BCE (Bernbeck \& Pollock 2016). The Aeneolithic level is subdivided into four strata with Stratum I as the youngest and Stratum IV as the oldest level. In these layers, extremely well preserved architecture with some walls standing to a height of up to $1.5 \mathrm{~m}$ was discovered. The excavated portions of the village suggest standardized, one-room and roughly square-shaped houses with two opposing buttresses, dividing the main room into an entry area, sometimes containing hearths or bins, and a back room that served mainly as a living space (Bernbeck et al. 2012: 15-16).

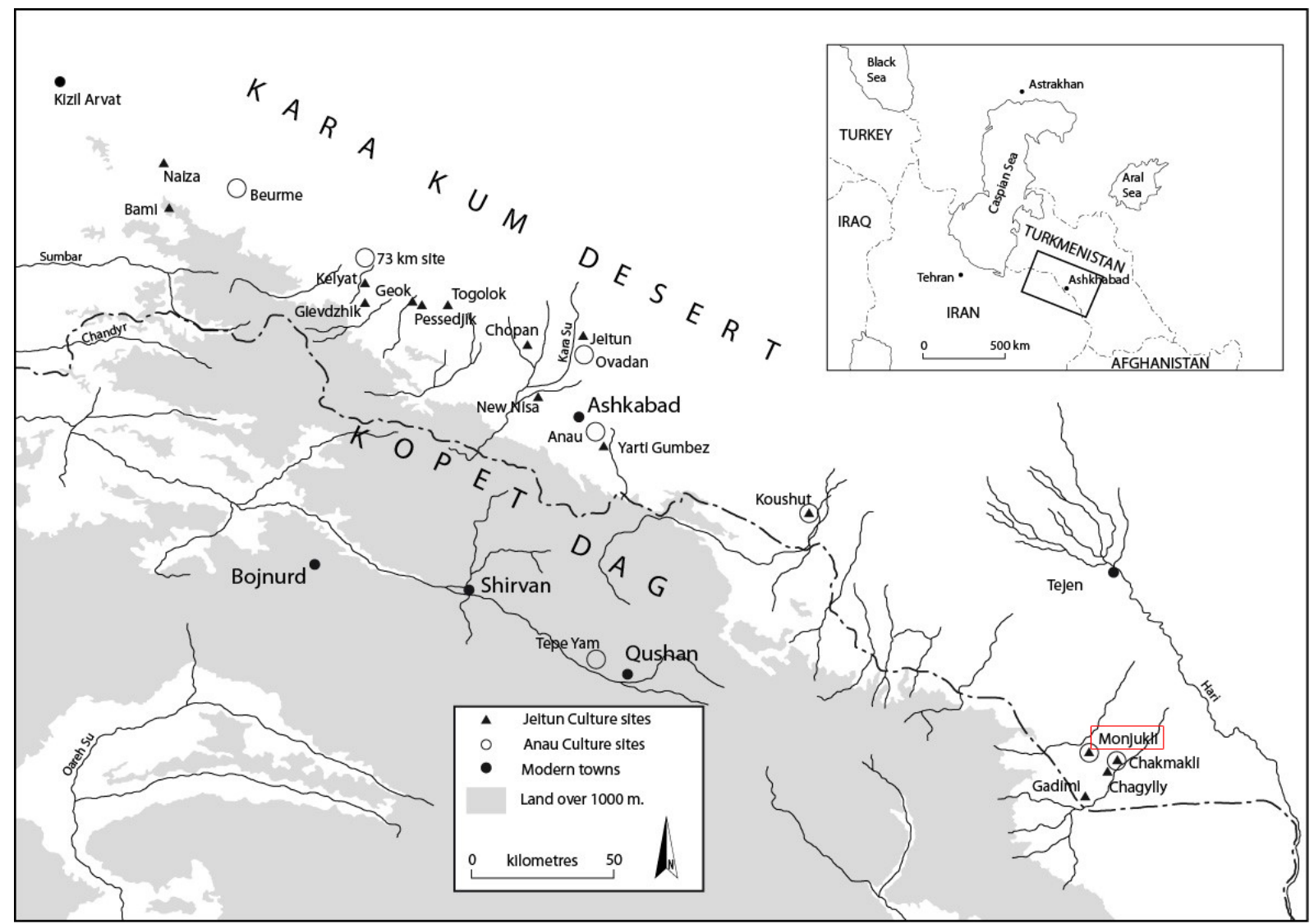

Figure 1. Monjukli Depe and other sites with Neolithic (Jeitun Culture) and Aeneolithic (Anau IA Culture) material (modified from Pollock et al. 2011: fig. 1).

The Aeneolithic village structure shows a contiguous build-up, interspersed with courtyard-like areas. The village was divided by at least two streets; the longer one runs from the north-western edge and leads to a gate in the east that could be closed. Behind the gate lay an open area which seems to have been used for communal feasting (Eger 2013: 40-47).

N. Miller, who examined the first excavation season's botanical finds, noted the presence of both glume and free-threshing wheat in the Aeneolithic levels at Monjukli. Wheat seems to predominate over barley, with six-row barley present in both the Neolithic and Aeneolithic occupations (Pollock et al. 2011: 219-221). Both the macrobotanical and phytolith analyses 
indicate the use of irrigation, presumably a simple form using gravity-flow (Pollock et al. 2011: 227). The faunal remains, which were analysed by N. Benecke and J. Eger, are heavily weighted towards domestic species, with over $80 \%$ being domestic sheep and goat; cattle also occur in significant numbers (Pollock et al. 2011: 211; Eger 2013). The identification of plant species from charcoal samples was performed by R. Neef whose findings indicate an arid environment similar to today (personal communication R. Neef, November 2013).

This paper focuses on a special group of grinding stones that are thought to have been used in plant-processing contexts. The following study was conducted after recovering typical grinding slabs known from Western Asia as saddle-shaped querns (Wright 1992: 63) with macroscopically detectable use traces of grinding - not to be confused with traces of postdepositional movement - often without any visible residues, but in some cases with a thick layer of ochre on the use surface. There were no striking differences in the archaeological context, or in any macroscopic feature - except for the presence of ochre - that would connect one particular type of stone to a specific type of activity, i.e. plants or mineral processing. After a closer examination of the grinding surface, regular pecking traces, especially around the concave use surface, were noted - not to be confused with pecking traces from percussion touches or pecking from the initial shaping of the stone. The most likely explanation for these pecking traces is that they were produced in order to obtain a desired property of the tool. These considerations were the basis for the following hypotheses. First, that the pecking or repecking traces were meant to roughen the use surface (e.g., Wright 1992: 57) to prevent the grain from rolling off the smooth surface. In the Kopet Dag mountain range no igneous rock like basalt is present, which is often used in Western Asia for grinding activities (Wright 1992) because of its durability and, in the case of vesicular basalt, because of the rough surface. The grinding stones from Monjukli Depe are made of limestone or sandstone, which in comparison to vesicular basalt is softer and smooth (Pollock et al. in press). In comparison with stones with the presence of ochre, these pecking traces were significantly more wornout. The pecking traces in the grinding depression on the use surface were almost invisible.

This led to the second hypothesis: The stones with ochre were first used as grinding stones for processing cereals, but could no longer be used for grinding grain at some point due to the worn-out pecking traces. However, these stones were still sufficient for milling minerals. This suggests the refutation of an attribution of grinding stones as solely for plant processing. The deep concave depression, which may have made the stone inappropriate for re-roughening, may be an argument in favour of this hypothesis. The question arising from this hypothesis can be expressed as follows: Is it possible to outline the stages of use of the stones?

\section{Methods and phytolith analyses}

Testing the first hypothesis regarding the pecking traces requires evidence of mainly cereal material on these stones. Regarding the second hypothesis it needs to be demonstrated that the ochre-covered grinding stones with worn-out pecking traces contain plant material from the initial plant processing activity.

First clues for plants that were processed on the site are often macrobotanical remains which were collected from the archaeological sediments. However, due to the grinding process, the unprocessed plants (in this case grains), are generally not preserved on the grinding surface. In some rare in situ cases at other sites, only the deposition of the unprocessed products near the grinding stones could lead to the conclusion that these plants were indeed used for grinding (e.g., in Gordion, see Burke 2010: 127). Generally, there are no macrobotanical remains recorded on the grinding stones. This is also the case in Monjukli 
Depe. However, phytolith analysis deals with microscopic remains of plants, and there is a higher probability of recognizing plant remains in the form of phytoliths (Figure 2).

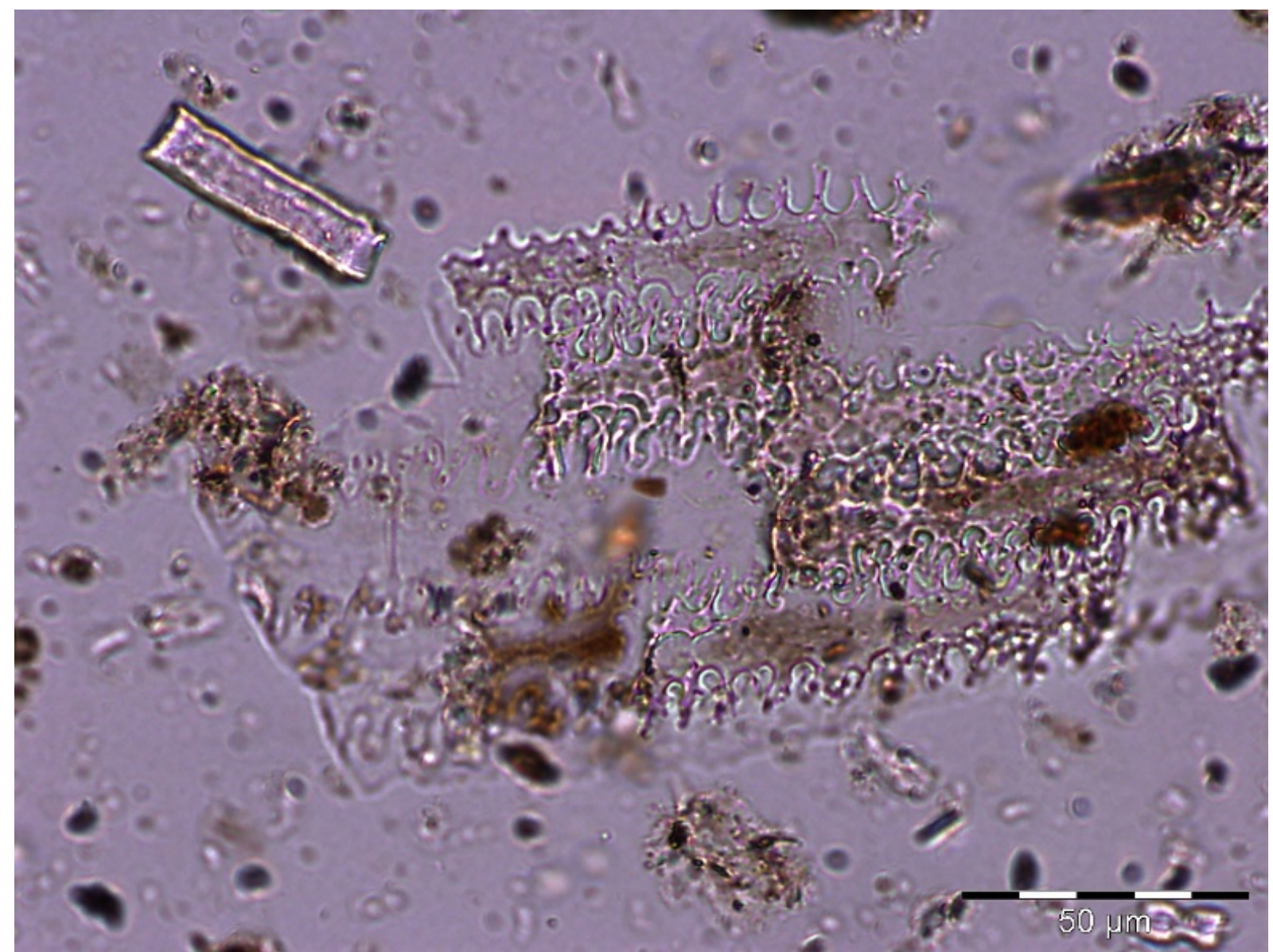

Figure 2. Phytoliths from sample B26.

Phytoliths are microscopic silica $\left(\mathrm{Si}(\mathrm{OH})_{4}\right)$ structures occurring in plant tissues (Piperno 2006: 9-15). These inorganic deposits form the different cellular structures of the plant and remain after the organic materials decay. Due to characteristics of the cell structures, it is possible to identify the plant type or even the part of the plant in which the phytolith was formed.

In principle, phytoliths can be divided into dicotyledons (hereafter dicots) and monocotyledons (hereafter monocots). For a better and simpler understanding, the word dicots will be replaced often by "tree or treelike", and for monocots with "grass". In cases that require more precision, the exact name of the plant species will be given. Furthermore, the correct botanical terminology of the plant parts will be replaced by generally used names, e.g., "husk". In this regard, husk will be used to indicate the outer membranous envelop of seeds (including the lemma, palaea und glume).

Within the grass family sweet grasses (Poaceae or Gramineae) or even sedges (Cyperaceae) can often be identified. Cereal types like wheat and barley, which belong to the Pooideae, a subfamily of sweet grasses, are in general easily identifiable. However, the distinction of cultivated and wild types is difficult and has been discussed with some controversy. In the case of some grasses which produce phytoliths, different morphotypes of phytoliths are formed in the husk, leaves, and stems. Tree phytoliths on the other hand can be separated into those which were produced in the wood or bark versus those from the leaves. 
In the fruits or seeds of plants phytoliths are absent and therefore their presence cannot be demonstrated which increases the importance of husk phytoliths.

Previous analysis conducted on different samples from Monjukli Depe by N. Miller (macrobotanical) and P. Ryan (phytoliths) is the basis for the premise that even if seeds do not produce phytoliths, the phytoliths in the seeds' enveloping husk are sufficient evidence for the seeds' presence. According to Miller (Pollock et al. 2011: 220), free-threshing wheat (Triticum aestivum; bread wheat) is noted in samples from the analysed period and seems to be one of the most frequently occurring cereals together with einkorn (Triticum monococcum), and six-row barley (Hordeum vulgare). These types were also detected in the phytolith analyses (Pollock et al. 2011: 225).

Furthermore, the phytolith results indicate that "the grass husk present in [some] storage contexts (...) are only from wheat, overall emphasizing glume wheat storage” (Pollock et al. 2011: 225). Even though Ryan (Pollock et al. 2011: 225) points out that "the free-threshing cereals (...), will be underrepresented in the phytoliths record from household contexts, since such cereals would most likely have been stored naked", the presence of these cereals has been proven by the analyses. On this basis, another premise will be applied to the phytolith analyses on the stones presented here: Even if on the grinding stones free-threshing cereals seeds that can be separated more easily from the husk - were processed, their presence is still provable since the seeds are not completely husk-free. Hodson et al. (2001) could prove that even from modern pasta samples husk phytoliths could be detected. A more reliable method for detecting grains would be starch analyses. However, in the samples from Monjukli Depe no starch could be identified.

Although larger pieces of connected phytoliths (hereafter multicells, which are especially important for the identification of plant species) "can be mechanically broken down" (Rosen \& Weiner 1994: 130), the grinding process does not destroy all plant cell formations. Therefore, at least the identification of tree or grass material, and in the best case the plant species, can be achieved (e.g., Rosen 1992; Piperno et al. 2009; Portillo et al. 2013).

\section{The analysed grinding stones}

The geographical location of Monjukli Depe is $8 \mathrm{~km}$ north of the Kopet Dag mountain range (Figure 1). The fringes of the site were covered for thousands of years with stone-less alluvial or aeolian layers, resulting in meters of silt and sand. Geoarchaeological work, however, revealed that the present day wadi, running at a distance of $c a .2 \mathrm{~km}$ from the site, did not run closer to the site in prehistoric times. It therefore can be assumed that the stones had to be brought into the settlement from some distance and that their presence is thus almost exclusively linked to human activity, even if they do not show processing or use traces.

The stones for this case study were all recorded during fieldwork as grinding stones and will be numbered for convenience from 1 to 5 . The selection of the sampled stones was accomplished primarily by the circumstances during fieldwork. Therefore stones had to be sampled directly during their recovery to get reliable material from the stone and the control areas around the stone. Stones 1 and 2 are from an installation found on a surface covered with red ochre, within Building 9 (Stratum III), with ashy material between the two stones. Stone 1 was covered with a thick layer of ochre; Stone 2 had only traces of ochre. Both stones were made of limestone and showed traces of use-wear (Figure 3), but no re-pecking traces were identified, similar to those mentioned above. 


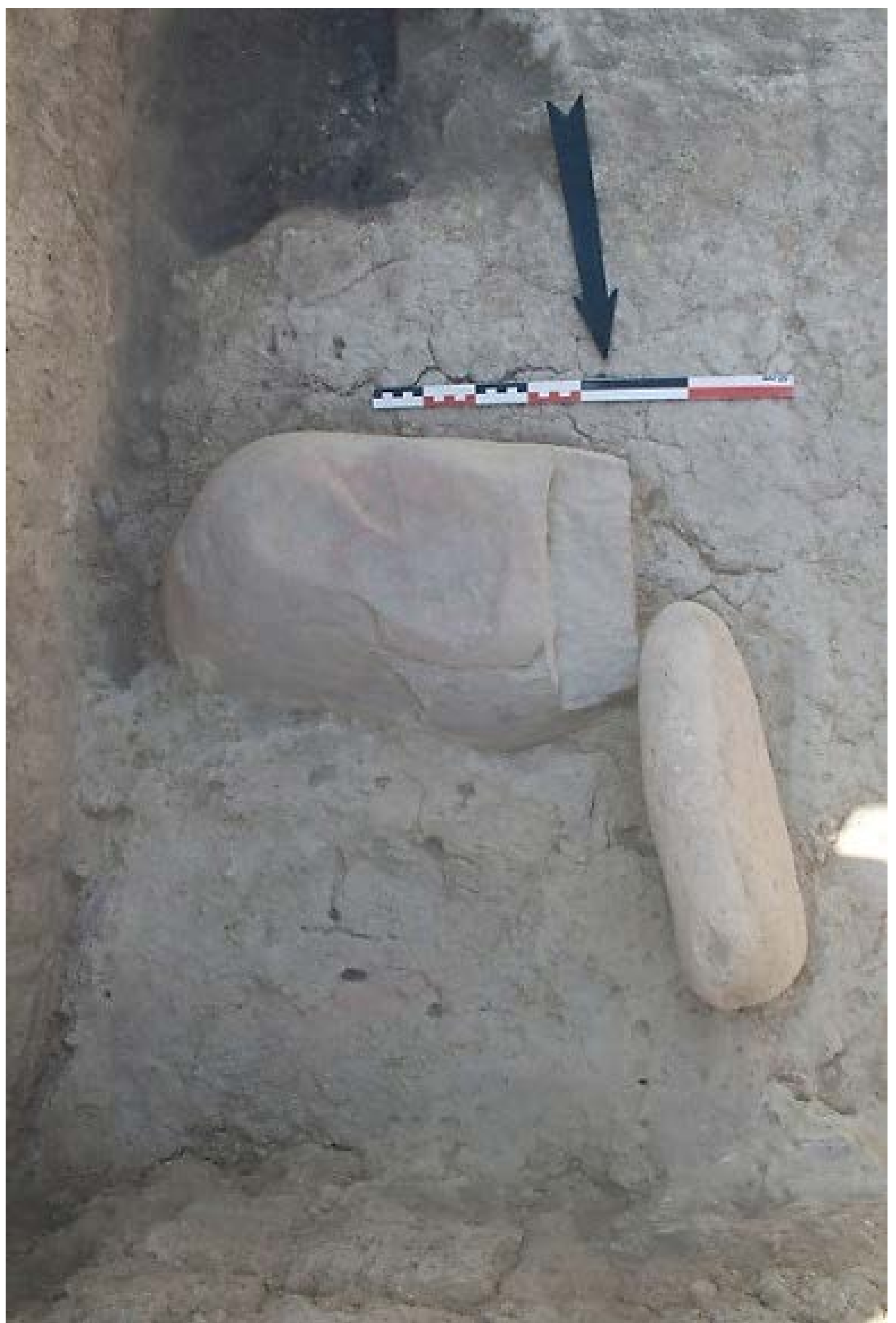

Figure 3. Stones 1 (larger) and 2. 
Stone 3 is a sandstone grinding stone, somewhat heart-shaped with slightly worn out pits (Figure 4). It lay in a material that contained a few patches of ochre directly above a surface of Building 11 (Stratum I).
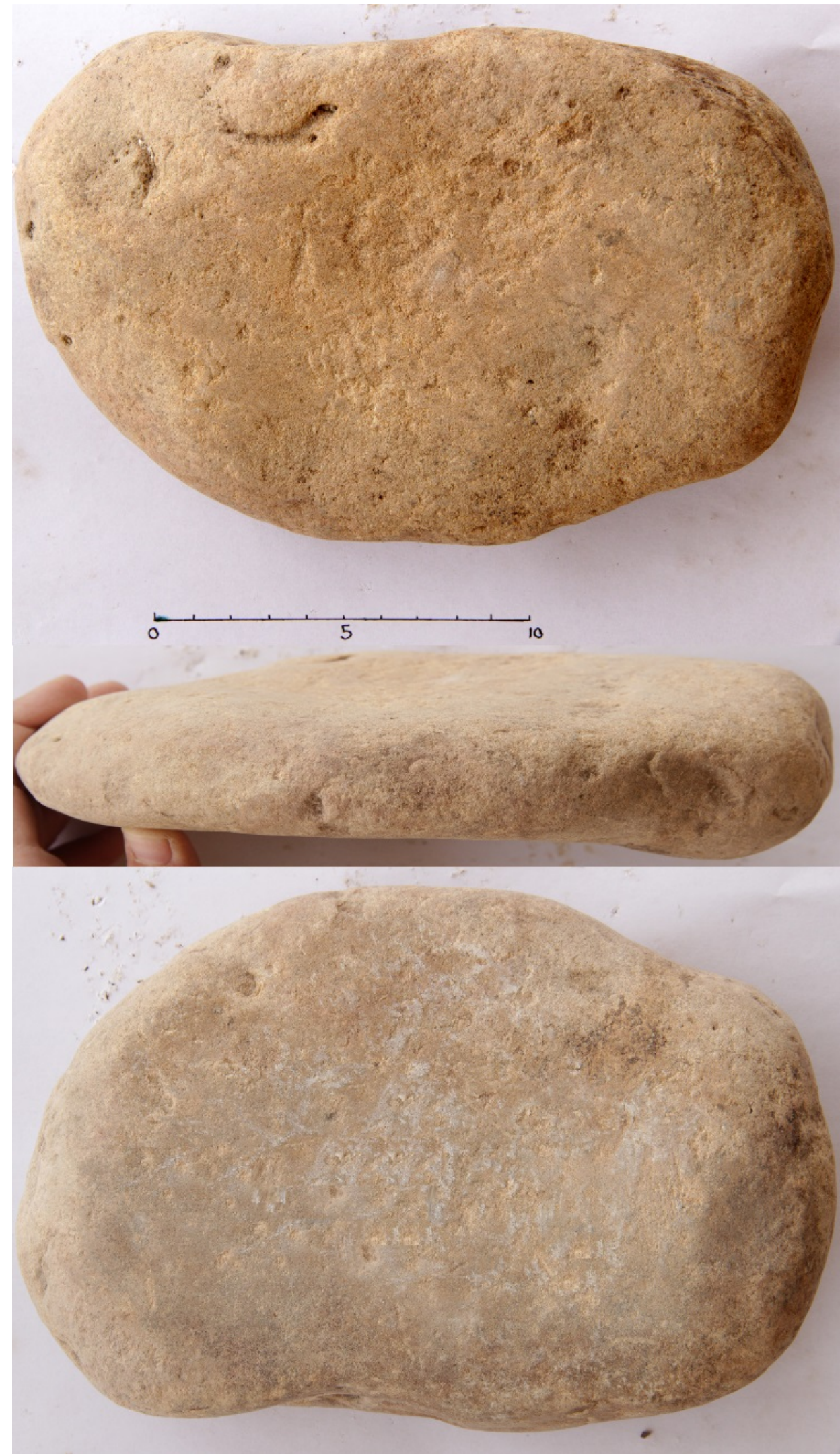

Figure 4. Stone 3. 
Stone 4 is a square shaped coarsely worked limestone with a slight depression in the middle (Figure 5). Pecking traces are visible outside of the depression. No traces of ochre were observed. The very rough surface of one of the edges (in Figure 5 side B), when compared to the elaborate processing of the other parts of the stone and the triangular profile, suggests that this stone is a broken (in Figure 5. B would be the broken edge) handstone that was then re-used for another purpose. This broken edge was worked only roughly, if at all before the slight depression was made. This stone was found on a floor in the north-western room of building 15 (Stratum I) near a wall close to a street.

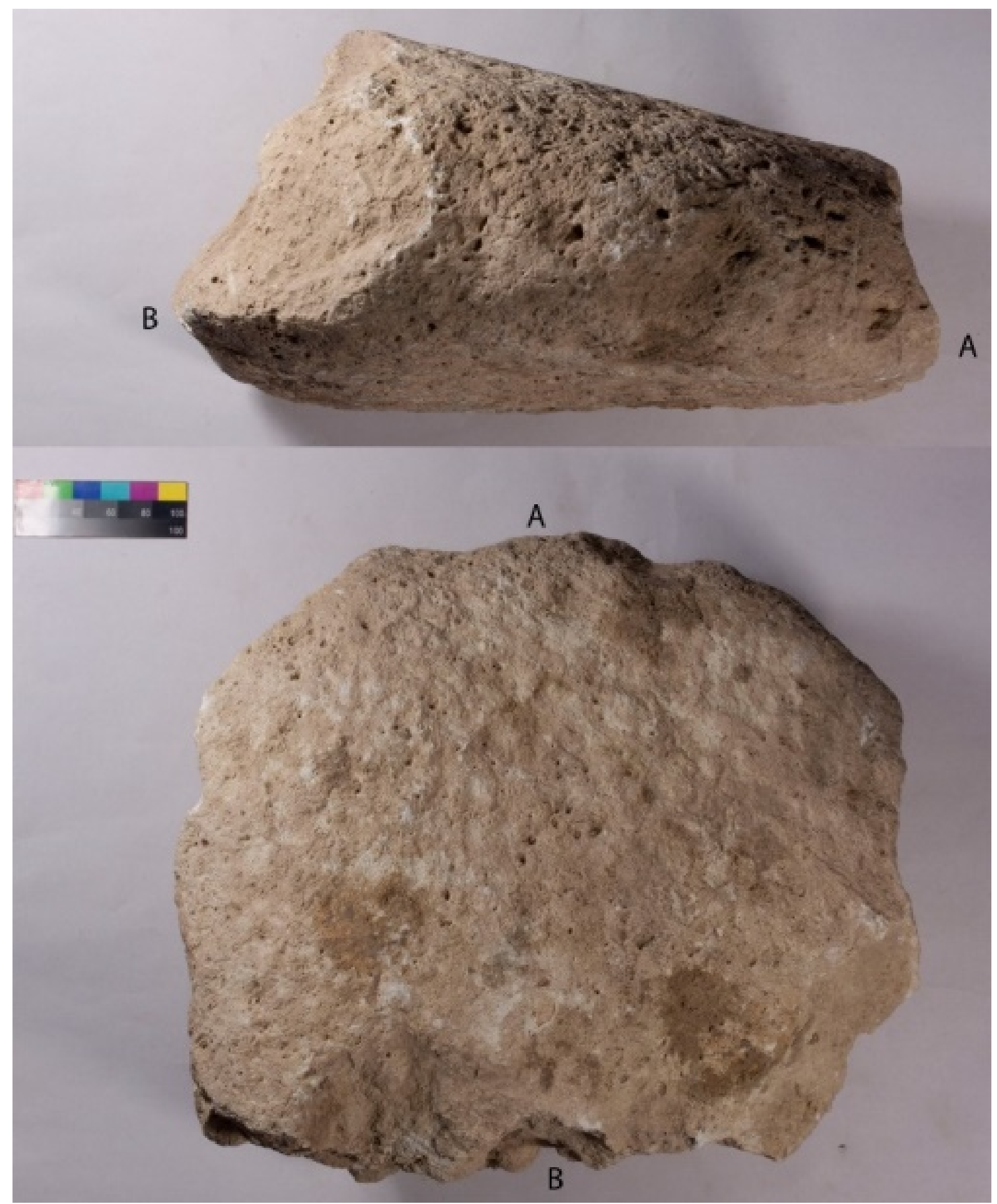

Figure. 5. Stone 4. 
Stone 5 is grinding stone made of sandstone, with worn out pits and fully covered with a thick layer of ochre (Figure 6). The use traces indicate that both sides were used. It was found in the debris of a collapsed wall amongst sizeable pieces of mudbrick in the southeastern room of Building 14 (Stratum IV).

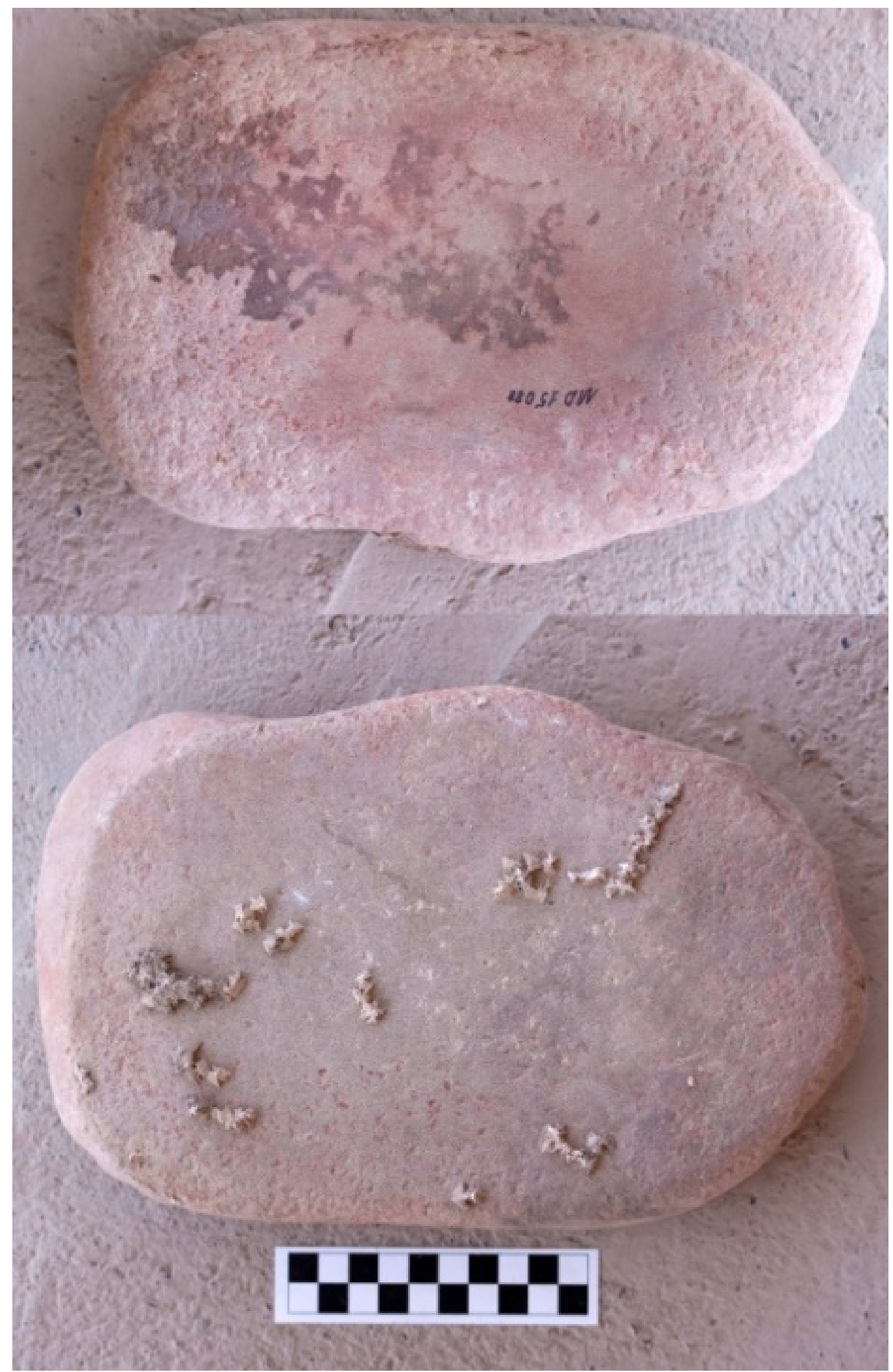

Figure 6. Stone 5, front (top) and reverse side (bottom). 
According to the contextual information, the macroscopically visible residues and traces, and the morphological features, different cases were compared (for a simplified summary, see Table 1). Stone 1 and 2 were without pecking traces, Stone 1 with ochre, and both were used in a room. Stone 1 was used, according to the use traces, as a slab. The other was likely used to stabilise the first stone. Stone 3 is a handstone with slightly worn-out pecking traces, visible grinding traces but without ochre. It was found on the floor surface of a room. Stone 4 is a slab with worn-out pecking traces, macroscopic grinding traces and no ochre, found on the floor surface of a room. Stone 5 is a slab with significantly worn-out pecking traces and a thick layer of ochre. According to the macroscopic use traces, this stone was used for grinding. This stone was the only one that was not found immediately above a surface, but rather in the debris of wall collapse in a room.

Table 1: Archaeological, macroscopic, and morphological data.

\begin{tabular}{|c|c|c|c|c|c|c|c|}
\hline $\begin{array}{l}\text { Stone } \\
\text { nr. }\end{array}$ & Shape & $\begin{array}{l}\text { Macroscopic } \\
\text { residue }\end{array}$ & $\begin{array}{c}\text { Macros. } \\
\text { production } \\
\text { traces }\end{array}$ & $\begin{array}{c}\text { Macroscopic } \\
\text { use wear }\end{array}$ & $\begin{array}{l}\text { Re-pecking } \\
\text { traces }\end{array}$ & $\begin{array}{c}\text { Worn } \\
\text { out }\end{array}$ & $\begin{array}{l}\text { On } \\
\text { floor }\end{array}$ \\
\hline 1 & $\begin{array}{l}\text { Grinding } \\
\text { slab }\end{array}$ & Ochre & Yes & Yes & No & & Yes \\
\hline 2 & $\begin{array}{l}\text { Function } \\
\text { unclear }\end{array}$ & Some ochre & No & No & No & & Yes \\
\hline 3 & Handstone & $\begin{array}{c}\text { None } \\
\text { (slightly } \\
\text { dark, } \\
\text { influence of } \\
\text { heat) }\end{array}$ & Yes & Yes & Yes & $\begin{array}{c}\text { Yes } \\
\text { (slightly) }\end{array}$ & Yes \\
\hline 4 & Mortar & None & $\begin{array}{c}\text { Yes } \\
\text { (secondary } \\
\text { use) }\end{array}$ & Yes & Yes & $\begin{array}{c}\text { Yes } \\
\text { (slightly) }\end{array}$ & Yes \\
\hline 5 & $\begin{array}{l}\text { Grinding } \\
\text { slab }\end{array}$ & Ochre & Yes & Yes & Yes & Yes & No \\
\hline
\end{tabular}

For the following analyses different sediment samples were taken: i) One from the environment around the stone as a control sample, ii) one from the top of the stone and ideally, if possible, immediately after the stone was recovered, iii) a sample brushed from the stone and iv) a sample washed from the stone with distilled water. As Table 2 below shows, samples were highly uneven in terms of the recovery of phytoliths on and around them.

\section{Phytolith processing methods}

The phytolith extraction method was performed according to the protocol described in Katz et al. (2010). The following report was undertaken under the guidance of M. Portillo at the Free University Geoscience Laboratories, using her protocol form described in Portillo et al. (2013: 208-209). The dried sediment was accurately weighed between 20 and $50 \mathrm{mg}$ and was treated with $50 \mu \mathrm{l}$ of a volume solution of $6 \mathrm{~N} \mathrm{HCl}$. The samples' mineral components were separated according to their densities. For concentrating the phytoliths $450 \mu \mathrm{l} 2.4 \mathrm{~g} / \mathrm{ml}$ sodium polytungstate solution $[\mathrm{Na} 6(\mathrm{H} 2 \mathrm{~W} 12 \mathrm{O} 40) \cdot \mathrm{H} 2 \mathrm{O}]$ was used.

After this, the microscope slides were mounted with $50 \mu \mathrm{l}$ of this suspension and were covered with a covering-slip. By counting the total number of fields containing phytoliths the aerial coverage of the sample on the slide was estimated. The counting of recognizable morphologies was based on a minimum of 200 phytoliths which were counted at $400 \times$ 
magnification. Unidentifiable phytoliths (damaged chemically or mechanically) were counted as weathered morphotypes. In order to assess differences in the range of phytolith size, multicellular structures were also counted. The description was mainly based on Portillo et al. (2013: 208-209). Morphological identification was based on the International Code for Phytolith Nomenclature (Madella et al. 2005).

\section{Phytolith results and interpretation}

The results of these quantitative analyses are presented in Table 2 with a focus on the distribution of grasses and tree materials, as well as the different parts of the plants.

Phytolith concentrations ranged from 225,094 to 2,862,144 phytoliths per gram of sediment with an average of 1,024,786 phytoliths per gram of sediment. The highest phytolith concentration was in the sample around and on Stone 5, which could be due to the find context. A significantly low quantity of phytoliths was recorded on all samples from Stones 1 and 2. These two stones seem to reflect the highest weathering rate as well, on Stone 1 up to $26 \%$ (all \% figures refer to the overall percentage of the phytoliths noted in each sample) and on Stone 2 up to $48 \%$. For all other stones this value was below $20 \%$.

Phytolith morphotype correspondences to plants or plant parts are based on Portillo \& Albert (2011: Table 2, 3228). According to this attribution grass phytoliths can be separated into leaves (mainly bulliform [fan and pillow shape], Epidermal appendage prickle, Long cell polylobate and wavy, Parallelepiped thin psilate, Silica skeleton longcell psilate, and wavy) and inflorescence, mainly Epidermal appendage papillae, Long cell echinate and dendritic, Parallelepiped thin psilate, silica skeleton long cell echinate (with papillae or short cells) and dendritic (with papillae or short cells). Short cell bilobate and chloridoid are characteristic for $\mathrm{C}_{4}$ grasses and Short cell Pooideae for $\mathrm{C}_{3}$ grasses. As stated in Faure \& Mensing (2005: 755), " $\mathrm{C}_{3}$ and $\mathrm{C}_{4}$ plants differ in the way that they metabolize $\mathrm{CO}_{2}$ during photosynthesis; $\mathrm{C}_{3}$ plants which include over $90 \%$ of all terrestrial plants including most cereals such as wheat and barley, rice, legumes, vegetables, nuts, fruits, and trees metabolise $\mathrm{CO}_{2}$ using the Calvin Cycle whilst $\mathrm{C}_{4}$ plants, which include maize, aquatic, arid, saltmarsh, and tropical grasses, utilise the Hatch-Slack pathway”. The same distinction can be made for dicot phytoliths, mainly Ellipsoid echinate for dicots in general, Ellipsoid smooth or rugose surface, Parallelepiped blocky, Parallelepiped thin rugose, Spheroid psilate or rugose for wood or bark and Epidermal appendage hair and hair base, Platelet, Silica skeleton polyhedral and Tracheary for dicot leaves.

The morphological results indicated that grasses are dominant in the samples (with a mean of $76 \%$ ), while inflorescences constitute up to $43 \%$ of all grass morphotypes, with a median of $c a$. 30\%. The lowest amount of phytoliths is from the samples from stones 1 and 2. As stated in Portillo et al. (2013: 213): "Inflorescences were characterized mainly by diagnostic papillae cells and decorated elongate echinate (elongate spiny) and dendritic long cells. According to the short cell morphologies, which are commonly formed both in grass leaves and inflorescences, grasses belonged to the $\mathrm{C}_{3}$ Pooid subfamily."

Tower short cell morphotypes, which are according to Portillo et al. (2013: 213) commonly produced in the Hordeum genus, were observed in very few quantities (ca. $1 \%$ of all short cells) and only in samples from Stone 5. Phytoliths characteristic for panicoids (Portillo et al. 2010: 24) were also noted, again in very low quantities. The highest amount was around 1\% in the samples around Stone 4. Ball et al. (2016) mention "Differentiating crop phytoliths from their Panicoid weedy wild relatives in archaeological contexts can present challenges due to similarities of identifiable Panicoid husk morphotypes, and large pristine sheets of identifiable multicellular aggregations that identification criteria (...) are, in part, based on are sometimes rare.”. Phytoliths common to the dicot family are in general very 
few, with a mean of 4\% for all samples. According to Gur-Arieh et al. (2013: 4336) "Past research showed that monocots (...) produce up to 20 times more phytoliths than dicot wood and bark and 16 times more phytoliths than dicot leaves". In almost all cases, except for Stone 4 , the amounts were not significantly above the average, whereas a sample from Stone 4 with over $7 \%$ is standing out.

Looking at the phytolith morphotypes that are characteristic for tree phytoliths, the distribution in all samples are between $1-2 \%$, whereas the difference is clearer if the wood or bark phytoliths are considered. Here the sample on Stone 4 with over $5 \%$ and $3 \%$ in one of the samples around this stone is striking.

The ratio between individual cells and multicells could provide the extent of silification (Rosen \& Weiner 1994; Albert \& Weiner 2001) and the preservation of fragile multicells. According to Portillo et al. (2014: 110) "the breakdown of multicellular forms may be dependent on varied taphonomic processes, including laboratory procedures such as acid extraction”. Actually the stones where plant processing is presumed should have a higher rate of individual cells. However, it should be considered that the soil around the stones is in all cases, except Stone 5, a surface that was most probably regularly walked upon, accounting for the breaking of multicellular phytoliths into individual cells.

\section{Discussion: Connecting the archaeological and the phytolith data}

The combination of the artefacts' shape, size, wear, the contextual information, and the tendencies from the phytolith analyses lead to the following conclusions (Table 3): regarding the installation, Stone 1 was used only for ochre, most likely in this place together with Stone 2. The differences in the amount of weathered morphotypes on the stones and around the stones are striking. This could be an indication for the use of some material on the stones that was not scattered around the stones.

The overall poor condition of the phytoliths of Stones 1 and 2 could indicate either a chemical process applied to the stone which dissolved the phytoliths or the abandonment of the area, exposing the stone to a long weathering process. Only the two diatoms, a group of algae (e.g., Werner 1977: 1-17), from the sediment around the stones could possibly support the latter argument.

Stone 3 is a typical grinding stone showing the expected results, with a high amount of grass inflorescences that indicate grinding activities involving grains that despite de-husking still contained a part of the husk. Due to the high amount of inflorescences on and around the stone, it was presumably used in that location, if we accept the assumption that the source of the high level of husk phytoliths in the surrounding soil derived from the grains' husk phytoliths processed on the grinding stone. If the husk phytoliths originated from the soil around the stones, then the phytoliths would be distributed on and around the stone on the same level, as can be seen in the case of Stone 5. However, the different percentages of multicell phytoliths (in the surrounding soil ca. twice as high as on the stone) and the phytoliths (in the surrounding soil $c a$. half of the amount on the stones) are an argument against this. The pecking traces were not worn out, so it was most probably still useable for grains. 
Table 2: Contextual, morphological and residue information and quantitative distribution of phytoliths. The density of phytoliths was calculated on the basis of the initial weight of the sediment in relation to the microscope's field size $\left(654 \mathrm{~mm}^{2}\right)$, counted fields and counted phytoliths. Percentages (\%) are according to all noted phytoliths in the sample. Abbreviations: dicot - phytoliths characteristic of dicotyledonous cells; ct. phyt. - count phytoliths; inflores. phyt. - inflorescence phytoliths.

\begin{tabular}{|c|c|c|c|c|c|c|c|c|c|c|}
\hline $\begin{array}{l}\text { Stone } \\
\text { nr. }\end{array}$ & $\begin{array}{l}\text { Lab } \\
\text { sample } \\
\text { nr. }\end{array}$ & Description and sampling & $\begin{array}{l}\text { Ct. phyt. in } \\
1 \text { g sample } \\
\text { material }\end{array}$ & $\begin{array}{c}\text { Phyt. } \\
\text { weathering } \\
(\%)\end{array}$ & $\begin{array}{l}\text { Multi cell } \\
\text { phyt. (\%) }\end{array}$ & $\begin{array}{l}\text { Individual } \\
\text { cell phyt. } \\
(\%)\end{array}$ & $\begin{array}{c}\text { Ratio } \\
\text { individual cell } \\
\text { and multi-cell }\end{array}$ & $\begin{array}{l}\text { Grass } \\
\text { phyt. } \\
(\%)\end{array}$ & $\begin{array}{c}\text { Inflores. } \\
\text { phyt. } \\
(\%)\end{array}$ & $\begin{array}{c}\text { Dicot } \\
\text { phyt. } \\
(\%)\end{array}$ \\
\hline \multirow[t]{4}{*}{1} & B19 & (i) soil around Stone 1 , and 2 & $1,024,786$ & 9.09 & 27.27 & 72.73 & 2.67 & 88.82 & 35.31 & 2.09 \\
\hline & B20 & (ii) soil on Stone 1 & 225,094 & 29.09 & 0 & 100 & - & 67.64 & 34.95 & 3.27 \\
\hline & B21 & (iv) soil washed from Stone 1 & $1,113,082$ & 22.12 & 11.98 & 88.02 & 7.35 & 75.39 & 29.34 & 2.49 \\
\hline & \multicolumn{2}{|c|}{ Mean soil from Stone $1(B 20, B 21)$} & 669,088 & 25.61 & 11.98 & 88.02 & 7.35 & 71.52 & 32.14 & 2.88 \\
\hline \multirow[t]{4}{*}{2} & B22 & (ii) on Stone 2 & 452,362 & 30.85 & 11.7 & 88.3 & 7.54 & 65.96 & 19.35 & 3.19 \\
\hline & B23 & (iii) on Stone 2, brushed & $1,070,190$ & 41.39 & 5.74 & 94.26 & 16.42 & 56.07 & 29.24 & 2.54 \\
\hline & B24 & $\begin{array}{l}\text { (iv) on Stone } 2 \text {, using distilled } \\
\text { water }\end{array}$ & 576,119 & 48.18 & 8.76 & 91.24 & 10.42 & 47.15 & 32.51 & 4.67 \\
\hline & Mean on & Stone 2 (B22, B23, B24 & 761,276 & 40.14 & 8.73 & 91.27 & 10.45 & 61.02 & 27.03 & 3.47 \\
\hline \multirow[t]{2}{*}{3} & B25 & (i) around Stone 3 & $1,484,991$ & 12.68 & 31.7 & 68.3 & 2.15 & 85.46 & 42.81 & 1.85 \\
\hline & B26 & (ii) on Stone 3, brushed & $1,083,013$ & 13.44 & 16.67 & 83.33 & 5.00 & 83.23 & 37.47 & 3.33 \\
\hline \multirow[t]{5}{*}{4} & B27 & (ii) on Stone 4) & $1,093,417$ & 19.17 & 6.25 & 93.75 & 15.00 & 73.58 & 31.14 & 7.25 \\
\hline & B28 & $\begin{array}{l}\text { (i) around Stone } 4 \text {, checkerboard } \\
\text { sample } 1 \text { from floor }\end{array}$ & $1,082,158$ & 9.18 & 4.35 & 95.65 & 21.99 & 86.67 & 26.76 & 4.15 \\
\hline & B29 & $\begin{array}{l}\text { (i) around Stone } 4 \text {, checkerboard } \\
\text { sample } 2 \text { from floor }\end{array}$ & $1,123,819$ & 13.43 & 6.94 & 93.06 & 13.41 & 81.30 & 19.36 & 5.28 \\
\hline & B30 & $\begin{array}{l}\text { (i) around Stone } 4 \text {, checkerboard } \\
\text { sample } 3 \text { from floor }\end{array}$ & $1,588,286$ & 12.18 & 1.68 & 98.32 & 58.52 & 82.69 & 12.2 & 5.13 \\
\hline & Mean ar & ound Stone 4 (B28, B29, B30) & $1,264,754$ & 11.6 & 4.32 & 95.68 & 22.15 & 83.55 & 19.44 & 4.85 \\
\hline \multirow[t]{2}{*}{5} & B31 & (ii) on Stone 5 & $2,093,062$ & 5.86 & 8.59 & 91.41 & 10.64 & 90.55 & 39.26 & 3.59 \\
\hline & B32 & (i) around Stone 5 & $2,862,144$ & 11.07 & 16.43 & 83.57 & 5.09 & 85.86 & 32.03 & 3.07 \\
\hline
\end{tabular}


Table 3: Summary of the main results of the archaeological and phytolith analyses Only those values that stand out as especially high or low are indicated in the table. Abbreviations: phyto. - phytoliths; WM - weathered morphotypes; MC - multicells; infl. - inflorescence; L - low; H - high.

\begin{tabular}{|c|c|c|c|c|c|c|c|c|c|c|c|c|c|}
\hline $\begin{array}{l}\text { Sediment } \\
\text { from }\end{array}$ & Ochre & $\begin{array}{l}\text { Second } \\
\text { use }\end{array}$ & $\begin{array}{l}\text { Found } \\
\text { on } \\
\text { surface }\end{array}$ & $\begin{array}{c}\text { Re- } \\
\text { pecking }\end{array}$ & $\begin{array}{l}\text { Worn } \\
\text { out }\end{array}$ & $\begin{array}{l}\text { Phyto. } \\
\text { amount }\end{array}$ & WM & MC & grass & $\begin{array}{l}\text { Grasses } \\
\text { infl. }\end{array}$ & tree & Interpretation function & $\begin{array}{l}\text { Interpretation } \\
\text { place of use }\end{array}$ \\
\hline Stone 1 & Yes & & Yes & No & & $L$ & & & & & $L$ & Grinding slab for ochre only & Likely in situ \\
\hline $\begin{array}{l}\text { Around } \\
\text { stone } 1\end{array}$ & & & & & & & $\mathrm{~L}$ & $\mathrm{H}$ & $\mathrm{H}$ & & L & & \\
\hline Stone 2 & & & Yes & No & & $\mathrm{L}$ & $\mathrm{H}$ & $\mathrm{L}$ & & $\mathrm{L}$ & $\mathrm{L}$ & Probably a supporting stone & Likely in situ \\
\hline $\begin{array}{l}\text { Around } \\
\text { stone2 }\end{array}$ & & & & & & & L & $\mathrm{H}$ & $\mathrm{H}$ & & L & & \\
\hline Stone 3 & & & Yes & Yes & $\begin{array}{c}\text { Yes } \\
\text { (slightly) }\end{array}$ & & L & & $\mathrm{H}$ & $\mathrm{H}$ & & $\begin{array}{l}\text { Grinding stone for plants } \\
\text { (probably used for grains) }\end{array}$ & $\begin{array}{l}\text { Likely in this } \\
\text { room }\end{array}$ \\
\hline $\begin{array}{l}\text { Around } \\
\text { stone } 3\end{array}$ & & & & & & & L & $\mathrm{H}$ & H & $\mathrm{H}$ & L & & \\
\hline Stone 4 & & Yes & Yes & Yes & $\begin{array}{c}\text { Yes } \\
\text { (slightly) }\end{array}$ & & & L & & & $\mathrm{H}$ & $\begin{array}{l}\text { Mortar (probably used with a } \\
\text { wooden pestle) or slab (possibly } \\
\text { used for a wooden construction, } \\
\text { like a door socket) }\end{array}$ & In this room \\
\hline $\begin{array}{l}\text { Around } \\
\text { stone } 4\end{array}$ & & & & & & & L & $\mathrm{L}$ & $\mathrm{H}$ & & & & \\
\hline Stone 5 & Yes & Yes & & Yes & Yes & & $\mathrm{H}$ & & $\mathrm{H}$ & $\mathrm{H}$ & & $\begin{array}{l}\text { Grinding slab for plants (possibly } \\
\text { used for grains) first, later for } \\
\text { ochre }\end{array}$ & Not in situ \\
\hline $\begin{array}{l}\text { Around } \\
\text { stone } 5\end{array}$ & & & & & & $\mathrm{H}$ & $\mathrm{L}$ & & H & & & & \\
\hline
\end{tabular}


Stone 4, with a depression in the middle and identified as a grinding stone, seems to be an ad hoc mortar. The samples from Stone 4 contained four times more tree phytoliths than the overall average in all of the analysed samples. This supports the idea of a wooden pestle being used on this stone. Another possibility could be a function as a door socket. However, it was found on a surface within the building and not directly connected to a wall. This and also the macroscopic use traces, which are indicative of linear use instead of a rotary motion in the depression, makes an identification as a mortar more plausible. Additionally, from the shape (figure 5, upper picture) it is possible to suggest that this stone was used as a grinding stone first and after it was broken the remaining part was turned into a mortar. The occurrence of (a low amount) of phytoliths common for panicoids on and around the stone, suggest in situ utilisation. Portillo et al. (2014: 115, referring to Rosen 2005), comment that "in Neolithic Çatalhöyük in central Anatolia, panicoids have been associated with decayed baskets and wheat husk phytoliths concentrations in domestic contexts, and interpreted to have been used for storing or cooking cereals and possibly other plant foods as well”.

Furthermore, it should be noted that multicells occurred most frequently in the samples taken around the stones, except for Stone 4, where they were only 4\%. This means that in the case of Stone 4 most probably no grass processing took place. The ratio of individual cells and multicells could confirm this suggestion.

Stone 5 has the typical shape of a grinding stone with worn-out pits and a thick layer of ochre. The phytoliths from the sample on the stone with a high level of grass phytoliths and inflorescences (most probably deriving from husks) suggest use in grain grinding activities. Combined with the presence of pits, in this case it is clear that this stone was first used as a grinding slab for grains as well as (later) for ochre.

If we try to interpret these outcomes, we could conclude for the installation (Stone 1 and 2) that the stones were tools used for mineral processing. It is still not very clear if this installation was used only for producing ochre powder. The macroscopic use traces tend to be produced by grinding. However, these are not as clear as on the other stones (e.g., Stone 5). Could this installation have been used for other activities which were conducted utilising ochre? At the moment, hints from the other grinding stones could indicate something like leather processing. However, this is still merely a possibility.

Regarding Stone 3 with the high similarity of grass and inflorescence phytoliths both on and around the stone, which point to an utilisation in situ, further questions concerning the distinction of domestic activities are raised: since it seems that this stone was used in a room of a building and if we assume that it was not transported to other places, is it likely that every house had its own grinding stone? To what extent were such objects shared? In this case the evidence afforded by the phytolith distribution suggests that this stone was used in this location and not shared by the other households. Additionally the pecking traces, which were not worn out completely, could be an indication that this stone was still in use. The production traces are not very prominent, so that in this case it was most probably this stone's natural shape when it was collected that fit well with the preferred shape of grinding stones.

The find context of Stone 5 gives a possible explanation for the differences in phytolith amount on and around the stone. Here the information from the shape of the stone and the use traces combined with the macroscopic (ochre) and microscopic (phytoliths) residues is again suggestive of multiple uses, either in consecutively or at the same time. This would argue for a repeated use of the same stone, as is the case for Stone 4.

\section{Conclusions: Possibilities and limits}

The results allow us to extract information with regard to the use of stones through the glimpse into the world of plants that phytolith analysis permits. However, the phytolith results 
alone cannot answer comprehensive issues, especially considering the still problematic identification of specific plant species and other open questions. These analyses can give only limited insight without corresponding archaeological data.

Nevertheless, through phytolith analyses it is possible to obtain clues for the distinction of plant families and plant parts. The durability of phytoliths provides the possibility to extract information from different archaeological contexts, where macrobotanical residues are no longer preserved. In Monjukli Depe there are macrobotanical materials which form a solid base concerning the plant species available at the site, but no remains are directly connected to the ground stone tools. In this regard phytolith analyses can provide a more precise connection of plants and stones.

There could be circumstances where phytoliths are not preserved, for example if the stones were washed several times during their use life. As demonstrated in this paper tracking the sequences of practices related to specific artefacts is possible by using a combination of different data. It can now be argued that activities connected to ochre are not solely the grinding of pigments. This could include practices which use ochre as an additive material, such as in leather processing (Ahlrichs 2015: 165-166). In this case the search for other kinds of activities in which ochre may have been used needs to be conducted.

The study demonstrates that the samples from stones with pecking traces contained a higher amount of grass phytoliths and often husk phytoliths as well. Due to the presence of husk phytoliths, the argument for a new or re-use phase could be strengthened. From the combination of morphological data and the worn-out surface, the second hypothesis can be confirmed, which stated that old grinding stones, which were not good enough for grinding grain anymore could be used for processing minerals. Research on similar objects could possibly answer the question of multi-functionality or re-use more precisely. However, it is clear that one stone was used in two different applications.

In addition to the sequence of use, one case (Stone 4) strongly hints at re-use in a different context, based mainly on the morphological data. With Stones 4 and 5 it is possible to get a glimpse into the consumption patterns of the inhabitants. We cannot say whether this evidence points to sustainable practices on the part of the inhabitants of Monjukli Depe. This would be an interesting question to pursue in future research. Moreover, the analyses draw attention to material categories that are, especially in the archaeological research of Western Asia, virtually disregarded.

An interesting subsidiary aspect is the question of whether an object was used at the location in which it was found. This cannot be answered reliably without contextual information. However, phytolith analysis can support the localisation, adding an important element to the biography of the stones. These new results show the potential of phytolith analyses in the examination of the social life of stones, with particular attention to the interpretation of their function, use phases (single events or sequences) and spatial dimensions, thereby bringing an understanding of past human activities closer to the present.

\section{Acknowledgements}

I would like to thank Dr. D. Rosenberg and all members of the organization team of the first meeting of the Ground Stone Tools Artefacts and Society. Without M. Portillo's generous help, patience and willingness to share her deep knowledge of phytolith analyses and the support of S. Pollock and R. Bernbeck this article could not have been written. Finally, I owe special thanks to S. Pollock and B. T. Irvine for their help to improve the English. 


\section{References}

Ahlrichs, J.J. 2015, Ocker im Paläolithikum. Universitätsforschungen zur Prähistorischen Archäologie Vol. 265. Rudolf Habelt Verlag, Bonn, 242 p.

Albert, R.M., \& Weiner, S. 2001, Study of phytoliths in prehistoric ash layers from Kebara and Tabun Caves using a quantitative approach. In: Phytoliths: applications in earth sciences and human history (Meunier, J.D. \& Colin, F., Eds.), A.A. Balkema Publishers, Lisse, Abingdon, Exton (PA), Tokyo: p. 251-266. doi:10.1201/NOE9058093455.ch19

Ball, T., Chandler-Ezell, K., Dickau, R., Duncan, N., Hart, T.C., Iriarte, J., Lentfer, C., Logan, A., Lu, H., Madella, M., Pearsall, D.M., Piperno, D.R., Rosen, A.M., Vrydaghs, L., Weisskopf, A. \& Zhang, J. 2016, Phytoliths as a tool for investigations of agricultural origins and dispersals around the world. Journal of Archaeological Science, 68: 32-45. doi:10.1016/j.jas.2015.08.010

Berdiev, O.К. 1972, Монжуклы Депе - Многослойное поселение неолита и раннего енеолита в южном Туркменистане. Каракумские Древности (Karakumskiye Drevnosti), 4: 11-34. (in Russian) ("Monjukli Depe - A multilayer settlement of the Neolithic and early Aeneolithic in southern Turkmenistan")

Bernbeck, R. \& Pollock, S. 2016, Scalar differences: temporal rhythms and spatial patterns at Monjukli Depe, Southern Turkmenistan. Antiquity, 90(349): 64-80. doi:10.15184/aqy.2015.197

Bernbeck, R., Pollock, S. \& Öğüt, B. 2012, Renewed excavations at Monjukli Depe. NeoLithics, 2(12): 15-19.

Burke, B. 2010, From Minos to Midas. Ancient cloth production in the Aegean and in Anatolia. Ancient Textiles Series Vol. 7. Oxbow Books, Oxford, Oakville, 206 p.

Eger, J. 2013, Studien zur Fauna des äneolithischen Monjukli Depe, Turkmenistan. Kontextuelle Untersuchungen. MA thesis at the Institut für Vorderasiatische Archäologie, Freie Universität Berlin, Berlin, 74 p. (in German) ("Studies on the fauna of Aeneolithic Monjukli Depe, Turkmenistan. Contextual Investigations”)

Faure, G. \& Mensing, T.M. 2005, Isotopes: Principles and Applications. John Wiley \& Sons, Hoboken, 928 p.

Gur-Arieh, S., Mintz, E., Boaretto, E. \& Shahack-Gross, R. 2013, An ethnoarchaeological study of cooking installations in rural Uzbekistan: development of a new method for identification of fuel sources. Journal of Archaeological Science, 40(12): 4331-4347. doi:10.1016/j.jas.2013.06.001

Hodson, M.J., Westerman, J. \& Tubb, H.J. 2001, The use of inflorescence phytoliths from the Triticeae in food science. In: Phytoliths: Applications in earth sciences and human history (Meunier, J.D., \& Colin, F., Eds.), A.A. Balkema Publishers, Lisse, Abingdon, Exton (PA), Tokyo: p. 87-100. doi:10.1201/NOE9058093455.ch5

Katz, O., Cabanes, D., Weiner, S., Maeir, A.M., Boaretto, E. \& Shahack-Gross, R. 2010, Rapid phytolith extraction for analysis of phytolith concentrations and assemblages during an excavation: an application at Tell es-Safi/Gath, Israel. Journal of Archaeological Science, 37(7): 1557-1563. doi:10.1016/j.jas.2010.01.016 
Kopytoff, I. 1986, The cultural biography of things: commoditization as process. In: The Social Life of Things. Commodities in Cultural Perspective (Appadurai, A., Ed.), Cambridge University Press, Cambridge, New York, Melbourne: p. 64-91. doi:10.1017/CBO9780511819582.004

Madella, M., Alexandre, A. \& Ball, T. 2005, International code for phytolith nomenclature 1.0. Annals of Botany, 96(2): 253-260. doi:10.1093/aob/mci172

Piperno, D.R. 2006, Phytoliths: A Comprehensive Guide for Archaeologists and Paleoecologists. AltaMira Press, Lanham, New York, Toronto, Oxford, 238 p.

Piperno, D.R., Ranere, A.J., Holst, I., Iriarte, J. \& Dickau, R. 2009, Starch grain and phytolith evidence for early ninth millennium B.P. maize from the Central Balsas River Valley, Mexico. Proceedings of the National Academy of Sciences of the United States of America, 106(13): 5019-5024. doi:10.1073/pnas.0812525106

Pollock, S., Bernbeck, R., Benecke, N., Castro Gessner, G., Daszkiewicz, M., Eger, J., Keßeler, A., Miller, N., Pope, M., Ryan, P. \& Sturm, P. 2011, Excavations at Monjukli Depe, Meana-Čaača Region, Turkmenistan, 2010. Archäologische Mitteilungen aus Iran und Turan, 43: 169-237.

Pollock, S., Bernbeck, R., Beckers, B., Benecke, N., Berking, J., Castro Gessner, G., Eger, J. \& Ögüt, B. in press, Archaeological work at Monjukli Depe: A regional perspective. Archäologische Mitteilungen aus Iran und Turan, 20 p.

Portillo, M. \& Albert, R.M. 2011, Husbandry practices and livestock dung at the Numidian site of Althiburos (el Médéina, Kef Governorate, Northern Tunisia): the phytolith and spherulite evidence. Journal of Archaeological Science, 38(12): 3224-3233. doi:10.1016/j.jas.2011.06.027

Portillo, M., Albert, R.M., Kadowaki, S. \& Nishiaki, Y. 2010, Domestic activities at Early Neolithic Tell Seker al-Aheimar (Upper Khabur, Northeastern Syria) through phytoliths and spherulites studies. In: Des hommes et des plantes. Exploitation du milieu et gestion des ressources végétales de la préhistoire à nos jours. XXXe rencontres internationales d'archéologie et d'histoire d'Antibes (Delhon, C., Théry-Parisot, I. \& Thiébault, S., Eds.), Éditions APDCA, Antibes: p. 19-30.

Portillo, M., Bofill, M., Molist, M. \& Albert, R.M. 2013, Phytolith and use-wear functional evidence for grinding stones from the Near East. In: Regards croisés sur les outils liés au travail des végétaux. An Interdisciplinary Focus on Plant Working Tools. Actes XXXIIIe rencontres internationales d'archéologie et d'histoire d'Antibes (Anderson, P.C., Cheval, C. \& Durand, A., Eds.), Éditions APDCA, Antibes: p. 161-174.

Portillo, M., Kadowaki, S., Nishiaki, Y. \& Albert, R.M. 2014, Early Neolithic household behavior at Tell Seker al-Aheimar (Upper Khabur, Syria): a comparison to ethnoarchaeological study of phytoliths and dung spherulites. Journal of Archaeological Science, 42: 107-118. doi:10.1016/j.jas.2013.10.038

Rosen, A.M. 1992, Preliminary identification of silica skeletons from Near Eastern archaeological sites: an anatomical approach. In: Phytolith Systematics. Emerging Issues (Rapp, G.R., \& Mulholland, S.C., Eds.), Advances in Archaeological and Museum Science Vol. 1, Plenum Press, New York: p. 129-147. doi:10.1007/978-14899-1155-1_7 
Rosen, A.M. 2005, Phytolith indicators of plant and land use at Çatalhöyük. In: Inhabiting Çatalhöyük: reports from the 1995-99 seasons (Hodder, I., Ed.), Çatalhöyük Research Project Vol. 4, McDonald Institute for Archaeological Research, British Institute of Archaeology at Ankara, Cambridge, London: p. 203-212.

Rosen, A.M. \& Weiner, S. 1994, Identifying ancient irrigation: a new method using opaline phytoliths from emmer wheat. Journal of Archaeological Science, 21(1): 125-132. doi:10.1006/jasc.1994.1013

Shanks, M. 1998, The life of an artifact in an interpretive archaeology. Fennoscandia Archaeologica, 15: 15-30. URL: http://www.sarks.fi/fa/PDF/FA15_15.pdf

Werner, D. 1977, Introduction. In: The Biology of Diatoms (Werner, D., Ed.), Botanical Monographs Vol. 13, Blackwell Scientific, Oxford, p. 1-17.

Wright, K. I. 1992, A classification system for ground stone tools from the prehistoric Levant. Paléorient, 18(2): 53-81. doi:10.3406/paleo.1992.4573 